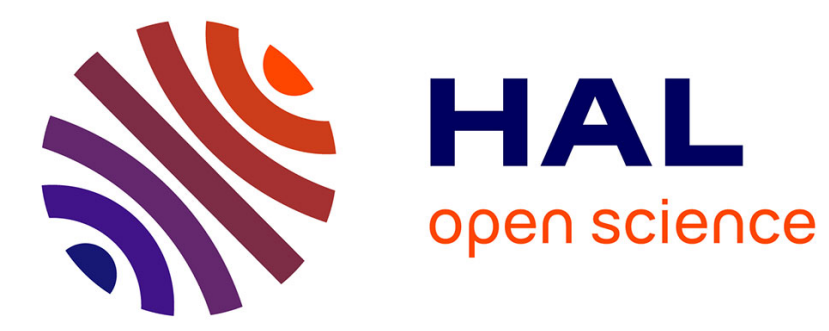

\title{
Transformation processes during annealing of Al-amorphous alloys
}

\author{
N. Petrescu, M. Petrescu, M. Calin, A. Jianu, M. Fecioru
}

\section{To cite this version:}

N. Petrescu, M. Petrescu, M. Calin, A. Jianu, M. Fecioru. Transformation processes during annealing of Al-amorphous alloys. Journal de Physique IV Proceedings, 1993, 03 (C7), pp.C7-243-C7-246. 10.1051/jp4:1993738 . jpa-00252156

\section{HAL Id: jpa-00252156 https://hal.science/jpa-00252156}

Submitted on 1 Jan 1993

HAL is a multi-disciplinary open access archive for the deposit and dissemination of scientific research documents, whether they are published or not. The documents may come from teaching and research institutions in France or abroad, or from public or private research centers.
L'archive ouverte pluridisciplinaire HAL, est destinée au dépôt et à la diffusion de documents scientifiques de niveau recherche, publiés ou non, émanant des établissements d'enseignement et de recherche français ou étrangers, des laboratoires publics ou privés. 


\title{
Transformation processes during annealing of Al-amorphous alloys
}

\author{
N. PETRESCU, M. PETRESCU, M. CALIN, A.D. JIANU* and M. FECIORU ${ }^{* *}$
}

Polytechnic Inst. Bucharest, Faculty Materials Science and Engineering, Spl. Independentei, 313 Bucharest, Romania

${ }^{*}$ IFTM-Bucharest

** DACLA Enterprise-Bucharest

\begin{abstract}
As the amorphous aluminum alloys represent the newest achievement in rapid solidification of Al-based high strength heat resistent materials, a study was undertaken on the amorphous alloys in the AI-RE-TM system, the rare-earth metal being a lanthanide mixture and the transition metal a $\mathrm{Ni}-\mathrm{Fe}$ substitution in definite proportions. The decomposition on heating of the most highly alloyed amorphous alloy in the investigated series is characterized by differential thermal analysis, electron microsm copy and X-ray diffraction.
\end{abstract}

General background

A new opening in the development of high-strength heat resistant light weight aluminium alloys has been brought about by the application of rapid solidification. The main strengthening mechanism in such "I iquid quenched alloys" is the solid solution strengthening resulting from the formation of a supersaturated solid solution containing solute elements far above their maximum high temperature equilibrium solubility limit. The solute content can be made even higher if an amorphous alloy may be produced by rapid solidification, because the amorphous phase can be regarded to be a kind of highly concentrated solid solution which has a homogeneous atomie distribution and a favorable atomic configuration so as to reduce the strain resulting from supersaturation.

Although the 1 iquid quenched crystalline Al-supersaturated solid solutions were well known since the very beginning of the rapid solidification development [1,2], giving rise to a new group of high strength aluminium alloys, -namely the Al-transition metals group-, the obtention of amorphous Al-based alloys is rather a new discovery. Amorphous Al alloys originate from the theoretical approach of the French researchers J.M.Dubois et G. Le Caer to define the amorphisation trend ofmetali ic melts by a short-range order modell governed by a local chemistry [3]. The principles of such a modell extended to Alalloys together with the results of the first successful experiments on an aluminium amorphous alloy (namely Alofu, Nig Mo $_{2}$ ) have been stated in a paper deposited in June 1982 to the Paris Academy of Sciences and published three years later. The ductile Al-Ni ternary amorphous alloys comprising either Si or Ge as an amorphisation non-metallic addition have marked in 1987 a new step. The latest and most interesting group of aluminium amorphous alloys intensively studied by. the Japanese researchers [4] comprises a rare earth-metal (Al-RE Systems) and an additional transition metal (Al-RE- TM systems). Qur research is concerned with this new group of amorphous aluminium alloys.

Results and discussion

Two series of AI-RE-TM alloys have been prepared and then rapidly solidified by melt spinning at $30 \mathrm{~m} / \mathrm{s}$ linear speed of the copper roller, $0.7 \mathrm{~mm}$ distance between nozzle and copper rolier surface and 785 mbar argon pressure. The compositions of the "as quenched" melt 


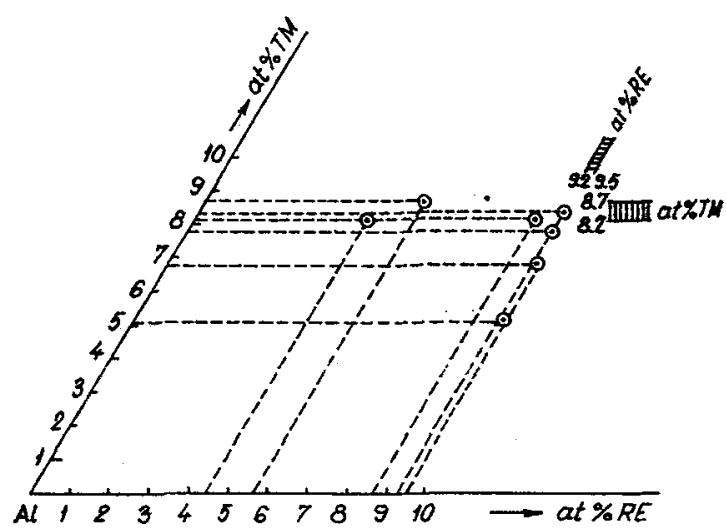

Fig.1 Composition location of the studied AI-RE-TM amorphous alloys. spun ribbons ( $\approx 30 \mathrm{~km}$ thick and $\approx 2 \mathrm{~mm}$ wide) have been determined by EDAX examination (Philips SEM 515 electron microscope equipped with $x$ ray energy dispersive spectrometers) and they are indicated on the composition triangle of a ternary Al-RETM phase diagram (fiq. 1). One series of these studied alioys lies witisn a nárow band of almost constant content in rare-earth metal (9.2-9.5 at\%), while the second series lies within a band of almost constant content in transition metal (日.2-B.7 at\% Th). The rareearth metal in our alloys was a mixture of lanthanides (a MischmetaLI) whose atomic percent composition Ce ${ }_{51} \mathrm{La}_{22} \mathrm{Nd}, \mathrm{Prgm}$ a corresponds to an average atomic weight $A=140.875 \mathrm{~g} / \mathrm{at} 0 \mathrm{~m} g$ that is very close to the atomic weight of cerium. The present paper will be concerned with the characterization of the alloy lying at the confluence of the two series in fig. 1, that is the richest alloy both in transition metal and in rare-earth metal. In addition the examined alloy presents a partial substitution of $\mathrm{Ni}$ by $\mathrm{Fe}$ in a proportion of about $1 / 3.5$ its precise composition ir ztomic percent being Al $\mathrm{B}_{4.3 E_{9.3} \mathrm{Fe}} \mathrm{Ni}_{6.3}$ or in a more convenient form Alse. RE 9.3 (Fe $0.22 \mathrm{Ni}_{0.79}$ ' $_{8,3}$
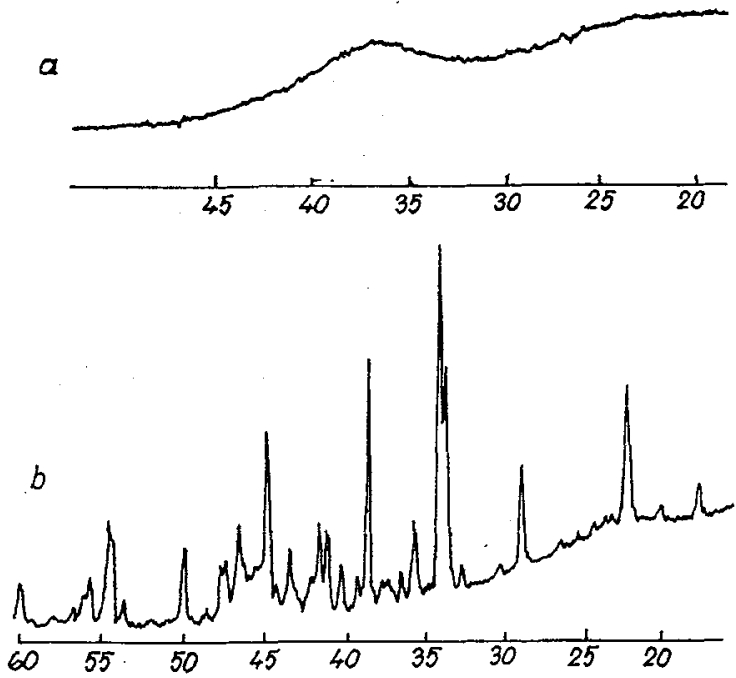

Fig.e x-ray diffraction patterns of

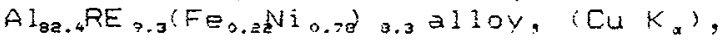
a) "as quenched"amorphous ribbon,

b) crystalline equilibrium structure.

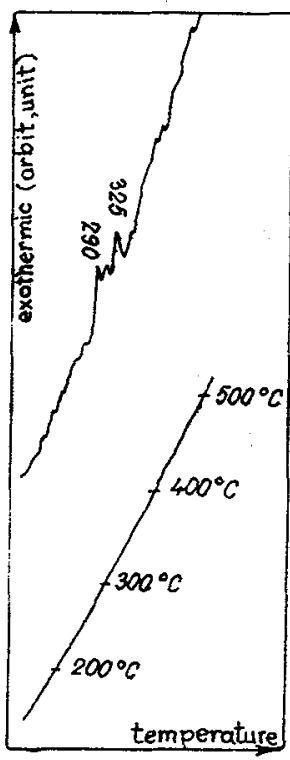

Fig. 3 DTA curve for the amorptious alloy (1000/min, in vaculim). 
hard, its vickers microhardness tested at 10 gf load being $235 \mathrm{kgf} / \mathrm{mm}^{2}$. Such a high level for hardness is characteristic for the amorphous Al-RE-TM alloys and it originates from a strong attractive atomic interaction and from short range ordering [4].

The amorphous state of the ribbon was confirmed by $x$ ray diffraction. The sharp Bragg peaks associated to crystallinity are completely absent in the diffraction pattern of the amorphous alloy (fia. 2a), while they are clearly manifest in the crystalline equilibrium structure of the same alloy (fig. 2b).

The changes in the structure of the alloy upon annealing have been investigated first by differentiel thermal analysis iotal and further by $X-r a y$ diffraction and scanning electron microscopy (SEM).

As seen from the DTA curve in fig. 3 two well defined exothermic peaks are manifest around $290^{\circ} \mathrm{C}$ and $325^{\circ} \mathrm{C}$ indicating that the amorphous alloy decomposes into a more stable state in a limited temperature range. In order to clarify the struetural changes due to the exothermic reactions, $x$ ray diffraction analyses were made after an 1 hour annealing applied to the amorphous alioy at different temperatures: at $250^{\circ} \mathrm{C}$ (before the first exothermic peak), at $300^{\circ} \mathrm{C}$ (before the second exothermic peak) and at $350^{\circ} \mathrm{C}$ (after the second exothermic peak). As seen from the $x-r a y$ diffraction patterns in fig. 4 a the amorphous state is not changed by 1 hour annealing at $250^{\circ} \mathrm{C}$. The $x$ ray diffraction pattern in fig. $4 \mathrm{~b}$ shows that some crystaliization has occurred during the first exothermic reaction at $290^{\circ} \mathrm{C}$. Finally the $x-r a y$ Iiffraction pattern in fia. 4 E irecorded atter i hour annealing at $350^{\circ} \mathrm{C}$ ) shows that a more intensive crystallization has occurred during the second exothermic peak at $325^{\circ} \mathrm{C}$; indeed peak positions and intensities are almost the same as for the equilibrium structure ( $f i q$ - 2b).

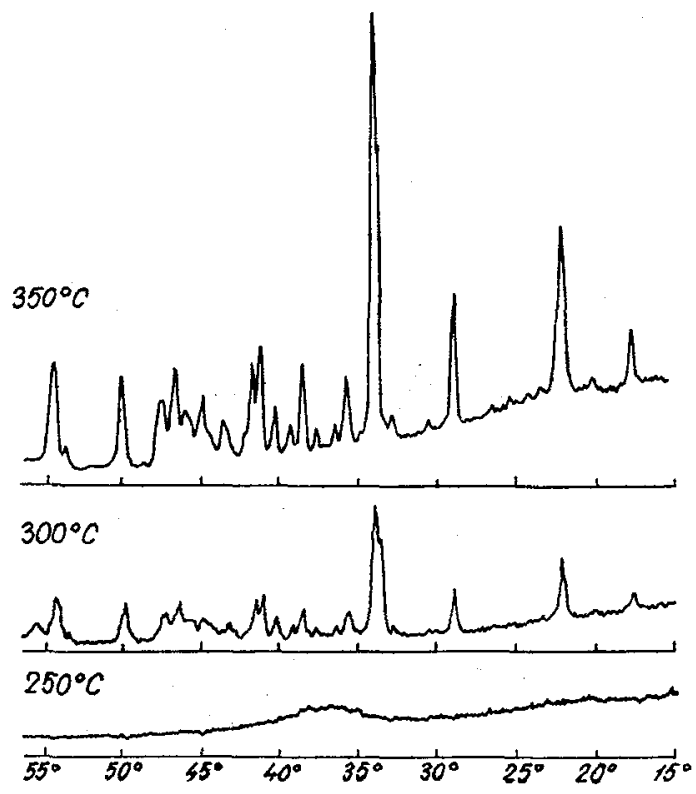

The crystalizized structure obtained after 1 hour annealing $3 t 350^{\circ} \mathrm{C}$ has then been examined at high magnification in a SEM electron microscope (fig. Sa,b). A heterogeneous structure is manifest showing a high proportion of fine particles rich in the heavy elements (RE and TM) -the white regions-. These extremely fine particles (0.1-0.5 um) consisting in Ai-RE-TM intermetallic compounds are embedded in the aluminium rich matrix (the black regions), the overall aspect being typical for a dispersion hardened structure. For sake of comparison the electron micrograph and the Al X-ray distribution image for the slowly solidified aijoy are also presented. It is obvious that the

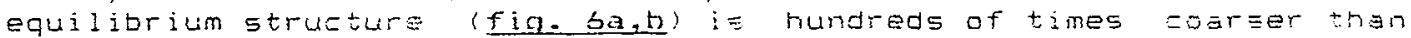
the structure obtained by amorpiazation followed by crystallization. 

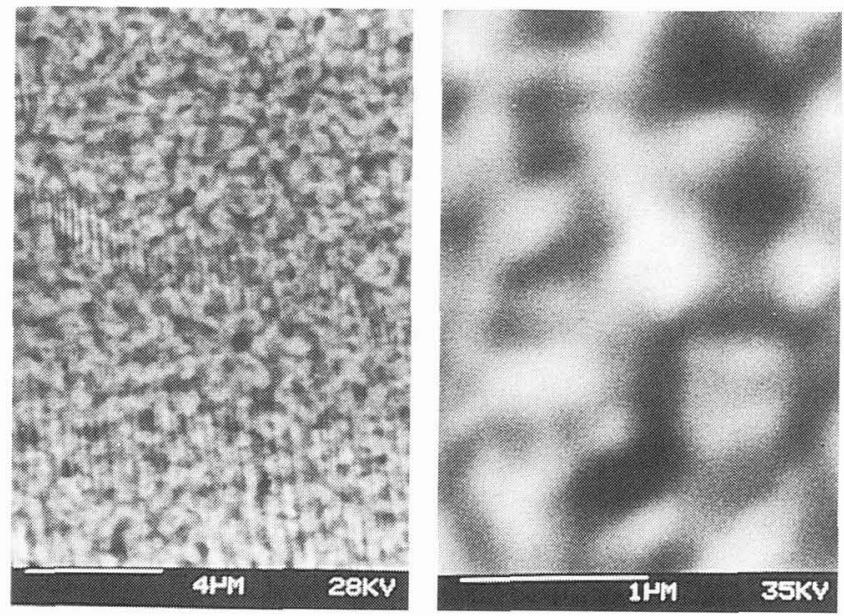

Fig.5 SEM mierographs of melt spun ribbon of Al $82.4 R E_{9.3}\left(F E_{0.22} \mathrm{Ni}_{0.78}\right)_{8.3}$ alloy after $350^{\circ} \mathrm{Cl} / \mathrm{h}$ ar gon annealing showing the decomposition erystallization of the amorphous solid solution:

a) 4250 magnification; b) 23500 magnification.
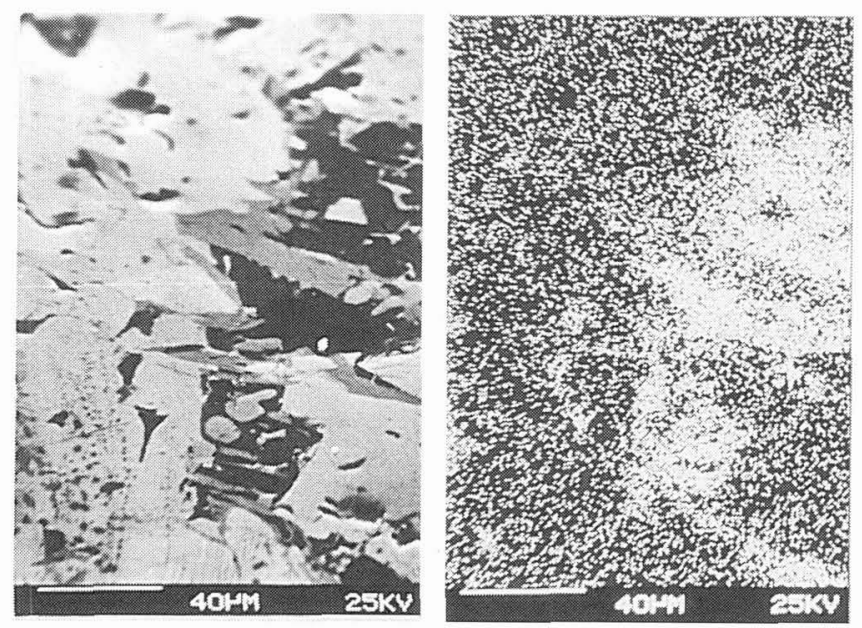

Fig.6 Equilibrium microstructure of slowly solidified

A $]_{82.4} R E_{9.3}\left(F \varepsilon_{0.22} \mathrm{Ni}_{0.78}\right)_{8,3}$

al $10 Y$ :

a) SEM micrograph;

b) $x-r a y$ image ( $A l \quad K_{\alpha}$ ) showing aluminium distribution.

\section{References}

[1]M.Petrescu,V.altean,M.Calin, Proceedings EUROMAT'91,1992,p.100

[2] H.Jones, "Aluminium", 1978, 54, P.274

[3] J.M.Dubois, G.Le Caer, Comptes Rendus. Acad. Sci. Paris,1985, t.301, serie II, nr.e, P.73

[4] A.Inove, T.Masumoto, Materials Science and Engineering, A133, $1991, p .6$ 